\title{
Sistem Pendukung Keputusan Penetapan Kenaikan Golongan Karyawan
}

\author{
Khoirun Nisa ${ }^{(\mathbb{})}$ \\ Program Studi Informatika, Universitas Harapan Bangsa, Purwokerto-Indonesia \\ khoirunnisa@uhb.ac.id
}

\begin{abstract}
PKU Muhammadiyah Sukoharjo Hospital is one of the hospitals that has 200 employees. To increase employee motivation to work, HR promotes the ranks of highly dedicated employees at the hospital by increasing the rankings through regular channels, so that it will automatically provide a reward. Meanwhile, the assessment is still not optimal due to the large number of appraisal resources and the absence of a system. So that the Decision Support System is used to make it easier to make assessments. This research of this system to test the accuracy of the system that is using TOPSIS method, BORDA, and SMARTER.
\end{abstract}

Smarter method helps in stabilizing the distance between the criteria by which the value of closeness reached $88.46 \%$ with the number of criteria by 26 , while 16 criteria by $56.25 \%$. The results of testing the accuracy using the confusion matrix method show that using the smarter method produces an accuracy value of 0.8 while without the smarter method it is 0.6 . The test results of the Smarter and Topsis methods have an accuracy value of 0.7 and an error rate of 0.25 . While the test uses the smarter method and borda with an accuracy of 0.7 and an error rate of 0.3 .

Keywords-TOPSIS, BORDA, SMARTER, confusion matrix, assessment

Intisari-Rumah Sakit PKU Muhammadiyah Sukoharjo sebagai salah satu rumah sakit yang memiliki sumber daya manusia dengan jumlah kurang lebih 200 pegawai. Dalam rangka meningkatkan motivasi karyawan bekerja, SDM melakukan penaikan pangkat kepada karyawan yang memiliki dedikasi tinggi di RS dengan menaikan golongon melalui jalur regular, sehingga secara otomatis akan memberikan sebuah reward. Sementara dalam penilaian masih kurang maksimal dikarenakan sumberdaya penilai yang banyak dan belum adanya sistem. Sehingga Sistem Pendukung Keputusan digunakan untuk mempermudah dalam melakukan penilaian. Sistem ini Penilitian ini melakukan pengujian tingkat akurasi pada sistem ini yang menggunakan metode TOPSIS, BORDA, dan SMARTER.

Metode smarter membantu dalam menstabilkan jarak antar kriteria dimana nilai kedekatan mencapai $88.46 \%$ dengan jumlah kriteria sebanyak 26, sedangkan 16 kriteria sebesar $56.25 \%$. Hasil pengujian akurasi menggunakan metode matriks confusion didapatkan hasil bahwa menggunakan metode smarter menghasilkan nilai akurasi sebesar 0.8 sedangkan tanpa metode smarter sebesar 0.6. Hasil pengujian metode Smarter dan Topsis memiliki nilai akurasi sebanyak 0.7 dan error rate 0,25 . Sedangkan pengujian menggunakan netode smarter dan borda akurasi sebesar 0,7 dan error rate 0,3 .
Kata Kunci- TOPSIS, BORDA, SMARTER, matrik confusion, penilaian

\section{PENDAHULUAN}

Rumah Sakit PKU Muhammadiyah Sukoharjo sebagai salah satu rumah sakit yang memiliki sumber daya manusia dengan jumlah kurang lebih 200 pegawai. Dalam rangka untuk meningkatkan motivasi karyawan dalam bekerja SDM melakukan penaikan pangkat keda karyawan yang memiliki dedikasi tinggi di RS dengan menaikan golongon melalui jalur regular, sehingga secara otomatis akan memberikan sebuah reward

Permasalahan yang terjadi disebabkan oleh sulit dalam menentukan karyawan yang akan dilakukan kenaikan golongan karena banyaknya karyawan dan subdivisi. Disisi lain penentuan kenaikan golongan dengan berbagai aspek masih didominasi unsur subyektif serta masih dengan manual.

Proses penentuan kenaikan golongan ini melibatkan banyak decision maker serta kriteria yang dinilai (multikriteria). Pengambil keputusan disini melibatkan dari bagian keislaman dan kemuhammadiyahan, bagian kepegawaian, serta direktur. Sehingga dalam penyelesaiannya diperlukan sebuah sistem pendukung keputusan yang dapat membantu para decision makers dalam menentukan keputusan yang tepat dan keputusan yang dilakukan lebih obyektif. Untuk mendukung solusi atas sebuah masalah atau mengevaluasi suatu peluang maka dibangun sistem pendukung keputusan [1]

Adapun penelitian terdahulu yang mendukung penelitian ini adalah penelitian yang sudah menerapkan TOPSIS dengan menggunakan metode borda. Penelitian yang dilakukan oleh Muhammad Hamka membuat sistem pendukung keputusan kelompok untuk penentuan bakal calon haji. Metode Topsis diterapkan untuk menghasilkan keputusan yang multikriteria setiap alternatif dinilai tidak hanya dari kelebihan tetapi juga kekurangannya. sedangkan metode borda mampu menyatukan setiap keputusan yang dihasilkan oleh masingmasing pengambil keputusan berdasarkan hasil pemeringkatan alternatif pada SPK individu sehingga hasil alternatif keputusan lebih obyektif[2].

Terdapat metode pengambilan keputusan yang bertujuan untuk mendapatkan alternatif yang terbaik berdasarkan kriteria tertentu. Metode tersebut disebut MCDM( Multi 
Creteria Decision Making). Kriteria biasanya aturan atau standar yang digunakan oleh pengambil keputusan. MCDM dibagi menjadi dua model : Multi Atributte Decision Making (MADM) dan Multi Objective Decision Making (MODM).

Metode TOPSIS dipilih dengan alasan dapat menyelesaikan pengambilan keputusan secara praktis, karena konsepnya sederhana dan mudah dipahami, komputasi efesien serta memiliki kemampuan kinerja relatif dari alternatifalternatif keputusan. Selain itu metode TOPSIS mampu menangani perbedaan alternatif walaupun perbedaannya cukup kecil, dalam metode TOPSIS sendiri ada namanya kaidah Cost dan Benifit untuk menentukan kaidah dalam masing-maisng kriteria.[3]

Metode merupakan metode pengambilan keputusan multikriteria yang diusulkan oleh Edwards dan Baron pada tahun 1994. Metode SMARTER merupakan pengembangan dari SMART (Simple Multi Attribute Rating Technique), kemudian dikembangkan lagi menjadi SMARTS (Simple Multi Attribute Rating Technique Swing). perbedaan SMART dan SMARTS terletak pada pembobotannya[4].

Selain itu memiliki keunggulan dalam perangkingan pada kasus dengan banyak kriteria namun kekurangannya terdapat pada pembobotan yang ditetapkan terlebih dahulu dan dihitung terlebih dahulu serta untuk perangkingan tunggal. Dikombinasikan dengan metode SMARTER memiliki kelebihan dalam melakukan pembobotan kriteria karena adanya pengecekan konsistensi jarak antar kriteria menggunakan metode ROC. penelitian ini menambahkan metode BORDA untuk pengambilan keputusan yang melibatkan beberapa kelompok pengambilan keputusan sehingga didapatkan hasil rangking alternatif ditiap-tiap kelompok pengambil keputusan untuk menghasilkan satu keputusan.

\section{TINJAUAN PUSTAKA}

Penelitian ini dilakukan dengan menggunakan tinjauan dari penelitian sebelumnya dengan tema yang sejenis dan menggunakan bagian dari penelitian tersebut sehingga dimodifikasi. Beberapa penelitian tersebut yaitu :

Penelitian terdahulu yang sudah dilakukan sebelumnya dengan menggunakan metode topsis dan borda adalah penelitian yang dilakukan oleh Muhammad menggunakan metode TOPSIS dan Borda untuk menerapkan spkk dalam pemilihan alternative bakal calon haji secara tepat. Penelitiannya menggunakan tiga kriteria yaitu kemuhammadiyahan dan keislaman, prestasi dan kinerja serta penilaian proses belajar mengajar. Maka dalam penelitian yang akan dilakukan menggunakan empat kriteria yaitu tes kemuhammadiyahan keislaman, penilaian kinerja, absensi karyawan dan penilaian rekomendasi direktur[.

Sistem pendukung keputusan kelompok penilaian kinerja kepala sekolah SMP berprestasi.Penelitian ini menggunakan metode TOPSIS, Profile matching dan borda. Dimana Profile matching digunakan untuk menentukan Gap memisahkan kriteria utama dan pendukung. Pada penelitian ini, pengambilan keputusan menggunakan lima kriteria yaitu kinerja kepala sekolah, portofolio presentasi dan wawancara, publikasi ilmiah serta tes tertulis. Perbedaan penelitian yang akan dilakukan yaitu metode yang digunakan dalam penelitian ini menggunakan SMARTER untuk menjaga konsistensi jarak setiap kriteria [5]

Penelitian SPK lainnya dilakukan oleh ikmah membahas pemodelan sistem pendukung keputusan menggunakan metode topsis dan borda. Pada penelitian ini, peneliti menggunakan dua kriteria yaitu tes microteaching dan tes psikologi. Penelitian tersebut juga menghasilkan model penelitian GDSS yang akan digunakan dalam penelitian yang akan dilakukan [6].

Selanjutnya penelitian yang membahas tentang penentuan karyawan kontrak menjadi karyawan tetap menggunakan metode topsis. Kriteria yang digunakan adalah kinerja, kedisiplinan, loyalitas, pengalaman kerja serta tingkat pendidikan. Perbedaannya, penelitian tersebut belum menggunakan metode pengambilan keputusan kelompok [7].

Penelitiannya yang berjudul "Sistem Pendukung Keputusan Penentuan Dosen dengan Kinerja terbaik" menggunakan metode topsis dan SMARTER. Penelitian ini menggunakan metode SMARTER dalam proses pembobotan kriteria, bobot hitung dengan menggunakan teknik ROC sehingga konsisten jarak antar kriteria dapat terjaga. Penelitian yang akan dilakukan menambahkan metode borda[8].

Penelitian yang berjudul Technical Approach of TOPSIS in Decision Making ini membahas tentang Sistem pendukung keputusan untuk pengambilan keputusan oleh manajer dengan menggunakan topsis [9].

Pada penelitian Sistem Pendukung Keputusan Seleksi Penerimaan Mahasiswa Pengganti Beasiswa Penuh Bidikmisi Universitas Tanjungpura dengan menerapkan metode SMARTER menarik kesimpulan bahwa metode SMARTER dapat melakukan seleksi penerimaan mahasiswa pengganti beasiswa penuh Bidikmisi dengan tingkat validitas sebesar $71,43 \%$ berdasarkan 17 (tujuh belas) data kasus calon mahasiswa pengganti beasiswa penuh Bidikmisi Universitas Tanjungpura [10].

Penelitian yang berjudul Multicreteria Decision making based on the Topsis method and similarity measures between intuitionistic fuzzy value memperoleh kesimpulakn bahwa dengan menggabungakn topsis dan fuzzy dapat mengatasi kelemahan dari metode josh dan kumar[11].

\section{Metodologi}

Data dalam penelitian ini berupa data karyawan, data peraturan kenaikan kepegawaian, data absensi karyawan, dan data kemuhammadiyahan dan penilaian kinerja yang dikumpulkan dai hasil observasi dan wawancara dengan bagian kepegawaian. Metode pada penelitian ini menggunakan metode Topsis, smarter dan borda untuk menganalisis data. Metode smarter untuk proses pembobotan kriteria dan topsis untuk proses perengkingan akhir penentuan kenaikan golongan karyawan.

Tahap dalam penelitian ini yang pertama melakukan proses perhitungan smarter dengan menentukan kriteria dan sub kriteria terlebih dahulu yang digunakan dalam proses penetapan. kemudian memberikan peringkat untuk setiap kriteria dan subkritera. Setelah itu menghitung bobot dari setiap kriteria dan subkriteria menggunakan teknik ROC didasarkan pada tingkat kepentingan atau prioritas dari 
kriteria. Tahap selanjutnya menghitung nilai utility yang dihasilkan dari penjumlahan setiap subkriteria dikali dengan nilai pembobotan kritera atau bobot ROC. Menghitung nilai pembobotan akhir dari suatu kriteria dalam perhitungan penetapan kenaikan golongan karyawan.

Tahap penelitian analisis data selanjutnya dengan menggunakn metode proses perangkingan, metode ini menggunakan prinsip bahwa alternatif yang dipilih harus mempunyai jarak terdekat dari solusi ideal positif dan terjauh dari solusi ideal negatif. Pada penelitian ini metode Topsis digunakan untuk proses perangkingan akhir penetapan kenaikan golongan karyawan dimana nilai bobot kriteria menggunakan hasil perhitungan pembobotan dengan model SMARTER. Langkah terakhir dari penelitian ini menggunakan metode borda untuk menentukan alternatif dari setiap decision maker yang melakukan pengambilan keputusan.

Pengujian tingkat akurasi pada penelitian ini menggunakan confusion matrix dimana untuk mengurangi kesalahan dan memastikan keluaran yang dihasilkan sesuai dengan yang diinginka. Nilai confusion matrix biasanya ditunjukkan dalam satuan persen $(\%)$. berikut gambar 1 alur penelitian.

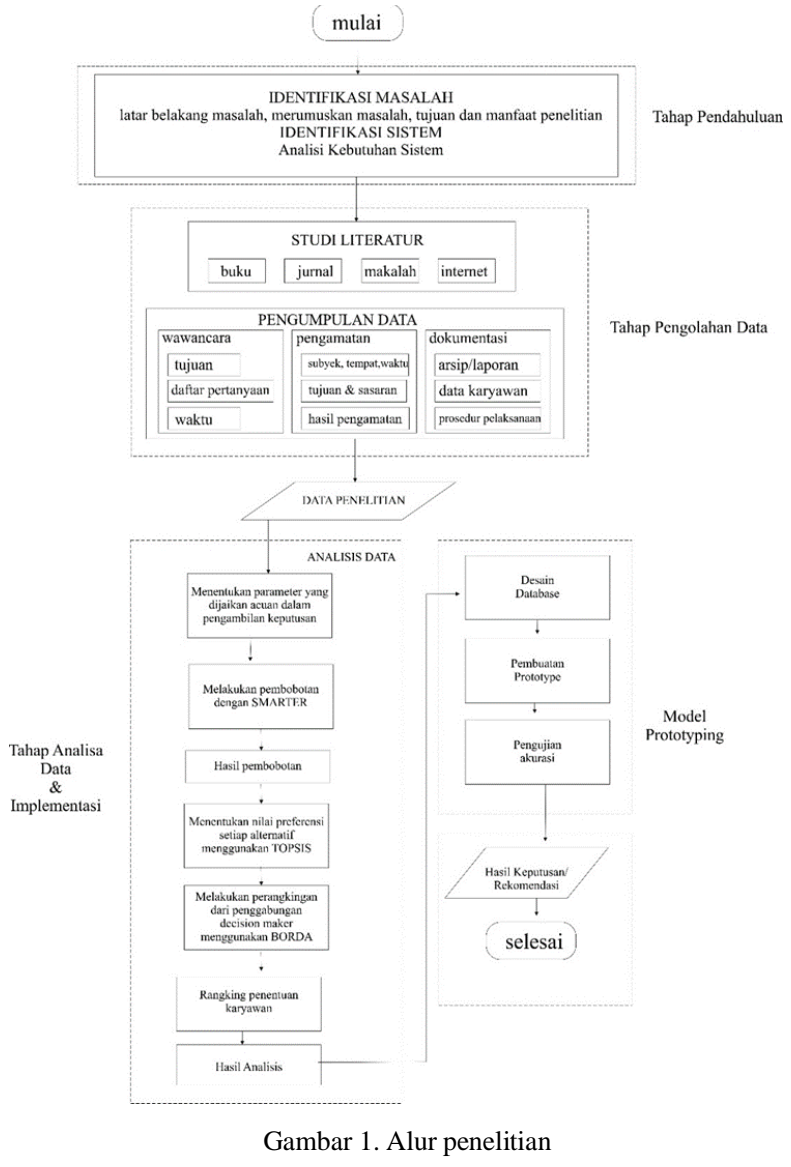

IV. HASIL DAN PEMBAHASAN

\section{A. Analisis Metode SMARTER}

Metode pembobotan yang menggunakan range antara 0 sampai 1, sehingga mempermudah perhitungan dan perbandingan nilai pada masing-masing alternatif. pembobotan ROC didapatkan dengan prosedur matematika sederhana dari prioritas. Ide dasarnya dapat diilustrasikan dengan 2 atribut $\mathrm{A}$ dan $\mathrm{B}$. jika A prioritas 1 maka bobotnya harus berada diantara 0,5 dan 1 sehingga titik tengah interval 0,75 diambil sebagai bobot perkeriaan, yang merupakan dasar dari sebuah prinsip komitmen minimum. seperti bobot B akan menjadi 0,25 (merupakan titik tengah antara 0 dan 0,5). Berikut langkah - langkah pembobotan menggunakan metode smarter :

Menentukan kriteria dan subkriteria Serta memberikan peringkat untuk setiap kriteria dan subkriteria. Prioritas disetiap kriteria ini berdasarkan wawancara dengan penilai. Kriteria ini dibagi menjadi dua penggunaan yaitu untuk kemuhammadiyahan dan kinerja karyawan dimana dibagi dua untuk penilaian karyawan non medis dan medis. Kriteria kinerja medis hampir sama dengan non medis perbedaannya hanya pada penambahan mutu pelayanannya.

Menghitung bobot dari setiap kriteria dan sub kriteria menggunakan teknik ROC. Metode ROC didasarkan pada tingkat kepentingan atau prioritas dan kriteria.

$$
\mathrm{Wk}=1 / \mathrm{k} \sum \mathrm{i}^{\wedge} \mathrm{k}=1(1 / \mathrm{i})
$$

Keterangan :

$$
\begin{array}{ll}
\mathrm{W} & =\text { Nilai pembobotan kriteria } \\
\mathrm{K} & =\text { Jumlah kriteria } \\
\mathrm{i} & =\text { Nilai alternatif }
\end{array}
$$

Rumus diatas dapat dijabarkan sebagai berikut:

$$
\begin{aligned}
& \text { If } \mathrm{W} 1 \geqslant \mathrm{~W} 2 \geqslant \mathrm{~W} 3 \geqslant \ldots . . \geqslant \mathrm{Wn} \\
& \mathrm{W} 1=(1+1 / 2+1 / 3+\cdots+1 / \mathrm{k}) / \mathrm{k} \\
& \mathrm{W} 2=(0+1 / 2+1 / 3+\cdots+1 / \mathrm{k}) / \mathrm{k} \\
& \mathrm{W} 3=(0+0+1 / 3+\cdots+1 / \mathrm{k}) / \mathrm{k} \\
& \mathrm{W} 3=(0+0+0+\cdots+1 / \mathrm{k}) / \mathrm{k}
\end{aligned}
$$

Menghitung nilai pembobotan Akhir. Pada perhitungan nilai akhir ini, nilai utility dikalikan dengan nilai bobot kriteria. Nilai ini akan digunakan dalam menentukan bobot akhir dari suatu kriteria dalam perhitungan. Nilai pembobotan akhir untuk kemuhammadiyahan terdapat pada tabel 2 dan kinerja terdapat pada tabel 3 dan nilai pembobotan akhir untuk kinerja non medis serta medis terdapat pada tabel 4.

Tabel 2. Nilai Akhir Kemuhammadiyahan Medis dan Non Medis

\begin{tabular}{|c|r|}
\hline $\mathbf{k}$ & W-BOBOT \\
\hline $\mathrm{k}-1$ & 0,457 \\
\hline $\mathrm{k}-2$ & 0,257 \\
\hline $\mathrm{k}-3$ & 0,157 \\
\hline $\mathrm{k}-4$ & 0,090 \\
\hline $\mathrm{k}-5$ & 0,040 \\
\hline
\end{tabular}

Tabel 3. Nilai Akhir Kinerja Non Medis

\begin{tabular}{|c|c|}
\hline $\mathbf{K}$ & W BOBOT \\
\hline $\mathrm{K}-1$ & 0,211 \\
\hline $\mathrm{K}-2$ & 0,149 \\
\hline $\mathrm{K}-3$ & 0,118 \\
\hline $\mathrm{K}-10$ & 0,034 \\
\hline $\mathrm{K}-11$ & 0,028 \\
\hline $\mathrm{K}-12$ & 0,023 \\
\hline
\end{tabular}




\begin{tabular}{|l|l|} 
K-4 & 0,097 \\
\hline K-5 & 0,081 \\
\hline K-6 & 0,069 \\
\hline K-7 & 0,058 \\
\hline K-8 & 0,049 \\
\hline K-9 & 0,041 \\
\hline
\end{tabular}

\begin{tabular}{|l|l|} 
K-13 & 0,017 \\
\hline K-14 & 0,013 \\
\hline K-15 & 0,008 \\
\hline K-16 & 0,004 \\
\hline
\end{tabular}

Tabel 4. Nilai Akhir Kinerja Medis

\begin{tabular}{|l|r|}
\hline K & W-BOBOT \\
\hline K-1 & 0,148 \\
\hline K-2 & 0,110 \\
\hline K-3 & 0,091 \\
\hline K-4 & 0,078 \\
\hline K-5 & 0,068 \\
\hline K-6 & 0,060 \\
\hline K-7 & 0,054 \\
\hline K-8 & 0,049 \\
\hline K-9 & 0,044 \\
\hline K-10 & 0,039 \\
\hline K-11 & 0,036 \\
\hline K-12 & 0,032 \\
\hline K-13 & 0,029 \\
\hline
\end{tabular}

\begin{tabular}{|l|r|}
\hline K & W-BOBOT \\
\hline K-14 & 0,026 \\
\hline K-15 & 0,023 \\
\hline K-16 & 0,021 \\
\hline K-17 & 0,018 \\
\hline K-18 & 0,016 \\
\hline K-19 & 0,014 \\
\hline K-20 & 0,012 \\
\hline K-21 & 0,010 \\
\hline K-22 & 0,008 \\
\hline K-23 & 0,006 \\
\hline K-24 & 0,005 \\
\hline K-25 & 0,003 \\
\hline K-26 & 0,001 \\
\hline
\end{tabular}

Dari hasil perhitungan smarter menghasilkan w-bobot yang berbeda-beda untuk setiap penilai. Pada bagian penilai kemuhammadiyahan dengan kriteria lima memiliki bobot tertinggi 0,457 dengan nilai keseluruhan bobot jika dijumlahkan hasilnya 1 . Sedangkan untuk penilai kinerja pada bagian non medis yang memiliki 16 kriteria dengan w-bobot tertinggi 0,211, kemudian hasil keseluruhan nilai bobot dijumlahkan menghasilkan 1. Penilai kinerja bagian medis dengan kriteria 26 memiliki w-bobot tertinggi 0,148 yang menghasilkan jumlah keseluruhan w-bobot 1 .

Jika masing-masing penilai bagian memiliki nilai keseluruhan w-bobot 1 maka dinyatakan ideal. Setiap kelompok kriteria memiliki nilai konsisten jarak yang berbeda, pada kriteria kinerja non medis yang mempunyai 16 kriteria memiliki nilai konsistensi 0.01 dengan prosentase $56.25 \%$, sedangkan nilai konsistensi pada kriteria kinerja medis yang memiliki 26 sebesar 0.01 sampai 0 dengan prosentasi $88.46 \%$. Kemudian dari hasil perhitungan w-bobot ini akan digunakan dalam perhitungan topsis untuk setiap penilai dengan kriteria masing-masing.

\section{B. Analisis Metode TOPSIS}

Metode TOPSIS digunakan untuk perangkingan pada masing-masing pengambil keputusan yaitu kemuhammadiyahan pada PDM dan direksi pada kepala unit, bagian kepegawaian, dan kepala bagian. Pada penelitian ini menggunakan nilai bobot kriteria hasil perhitungan dengan metode Smarter. Langkah - langkah dalam metode Topsis sebagai berikut :

\section{Membuat matriks nilai kriteria}

Matriks nilai kriteria diambil dari hasil penilaian kemuhammadiyahan dan kinerja karyawan pada tahun
2017/2018. Dimana hasil penilaian ini akan diadopsi menjadi nilai alternatif terhadap kriteria pengambilan keputusan.

\section{Menormalisasi matriks perbandingan berpasangan}

Data matriks keseluruhan untuk penilaian kemuhammadiyahan dan kinerja. Normalisasi matriks merupakan upaya menyatukan setiap elemen matriks, sehingga elemen pada matriks memiliki skala nilai yang sama. Perhitungan normalisasi matriks keputusan tiap kriteria untuk alternatif karyawan non medis dan karyawan medis menggunakan perhitungan rating ternormaliasi dari tiap alternatif dan kriteria, maka dihitung dengan

$$
\mathrm{rij}=\frac{x i j}{\sqrt{\sum_{i=1}^{m} X_{i j}^{2}}}
$$

$\mathrm{i}=1,2, \ldots ., \mathrm{m}$; dan $\mathrm{j}=1,2, \ldots ., \mathrm{n}$

Berikut contoh penjabaran dari rumus diatas untuk Perhitungan matriks ternormalisasi pada masing-masing kriteria:

Perhitungan nilai dari kriteria ke-1 (K-1) pada penilaian kemuhammadiyahan dengan alternatif A1 non medis dan medis

$\mathrm{C} 1($ non medis $)=\sqrt{ } 22+\ldots .2+32=18,4120$

Maka nilai matriks ternormalisasi untuk alternatif,

$\mathrm{A} 1=2 / 18,4120=0,1086$,

Sedangkan,

$\mathrm{C} 1($ medis $)=\sqrt{ } 42+\ldots .2+42=21,5407$

Maka nilai matriks ternormalisasi untuk alternatif,

$\mathrm{A} 1=4 / 21,5407=0,1857$

Perhitungan nilai dari kriteria ke-1 (K-1) pada penilaian kinerja untuk non medis dengan alternatif $\mathrm{A} 1$

$\mathrm{C} 1=\sqrt{ } 42+32+\ldots .2+32=17,3781$

Maka nilai matriks ternormalisasi untuk alternatif,

$\mathrm{A} 1=4 / 17,3781=0,1086$

Hasil dari perhitungan nilai tiap alternatif terhadap kriteria yang sudah ternormalisasi membentuk matriks $\mathrm{R}$.

\section{Membuat matriks normalisasi terbobot}

Matriks ternormalisasi terbobot dihasilkan dari perkalian matriks yang telah ternormalisasi dengan bobot, dimana bobot yang digunakan didapat dari hasil perhitungan model SMARTER bobot (Wi) pada tabel 2 dan tabel 3 sebagai berikut. Rumus dasar untuk menghitung matriks terbobot seperti persamaan 3 berikut ini.

yij $=$ wijrij

Keterangan :

yij = matriks ternormalisasi terbobot

wij = bobot

rij = matriks ternormalisasi

Dibawah ini uraian dari perhitungan matriks ternormalisasi terbobot untuk kemuhammadiyahan medis dan 
non medis serta kinerja medis dan non medis, untuk data matriks ternormalisasi terbobot

Nilai matriks ternormalisasi terbobot pada penilaian kemuhammadiyahan non medis dan medis

$$
\begin{aligned}
& \mathrm{Y}(1,1)=0,1086 * 0,457=0,0496 \text { (non medis), } \\
& \mathrm{Y}(1,1)=0,1857 * 0,457=0,0849 \text { (medis) }
\end{aligned}
$$

Nilai matriks ternormalisasi terbobot pada penilaian kinerja non medis

$$
\mathrm{Y}(1,1)=0,1086 * 0,211=0,02302
$$

Nilai matriks ternormalisasi terbobot pada penilaian kinerja medis

$$
\mathrm{Y}(1,1)=0,0857 * 0,148=0,0275
$$

\section{Menentukan solusi ideal positif dan ideal negatif}

Langkah selanjutnya menentukan nilai solusi ideal positif dan negatif. Solusi ideal dinotasikan A+, sedangkan solusi ideal negatif dinotasikan A-. Matriks solusi ideal berdasarkan normalisasi terbobot dan atribut kriteria (cost atau benefit). Solusi ideal positif diambil darinilai maksimal dari normalisasi terbobot jika atribut kriteria benefit, jika cost nilai minimalnya. Sedangkan, nilai ideal negatif diambil nilai minimal dari normalisasi terbobot jika atribut kriteria benefit, jika cost diambil maksimalnya.

$\mathrm{A}+=\left(y_{1}^{+}, y_{2}^{+}, \ldots, y_{n}^{+}\right) ; \mathrm{A}-=\left(y_{1}^{-}, y_{2}^{-}, \ldots, y_{n}^{-}\right)$;

Hasil solusi ideal positif dan solusi ideal negatif akan digunakan untuk menghitung jarak tiap alternatif terhadap solusi ideal positif dan solusi ideal negatif. Masing-masing penilai dan kelompok memiliki hasil solusi ideal yang berbeda.

\section{Perhitungan jarak antara nilai terbobot setiap alternatif}

Perhitungan jarak antara nilai terbobot setiap alternatif terhadap solusi ideal positif A+ dan solusi ideal negatif A-

6. Tahap akhir Perhitungan kedekatan setiap alternatif terhadap solusi ideal

Pemilihan sepuluh alternatif ditiap kelompok alternatif pada masing-masing keputusan penilai 1 dan penilai 2 untuk diagregasikan menjadi keputusan kelompok. Dengan perhitungan borda untuk mengagregasikan keputusan individu menjadi keputusan kelompok berdasrkan rangking alternatif dan nilai preferensinya.

\section{Analisis Metode BORDA}

Metode ini digunakan untuk menggabungakan hasil keputusan topsis antara penilai satu dan penilai kedua. Penelitian ini mengambil peringkat sepuluh dari masingmasing kelompok bagian karyawan yaitu dari non medis dan medis. Sehingga hasil akhir dari metode borda ini merupakan peringkat tertinggi dari penggabungan penilai 1 dan penilai 2 . Perhitungan metode borda dengan melakukan pengambilan poin borda alternatif,untuk mendapatkan hasil perhitungan dilakuakan perkalian antara bobot rangking dan nilai alternatif (Vi), Jumlah poin borda keseluruhan alternatif. Sedangkan nilai borda hasil pembagian poin borda dengan jumlah poin borda kemudian diurutkan dari nilai borda terbesar sebagai rangking 1 dan seterusnya.
Tabel 5. Perhitungan Menggunakan Metode Borda Bagian Non Medis

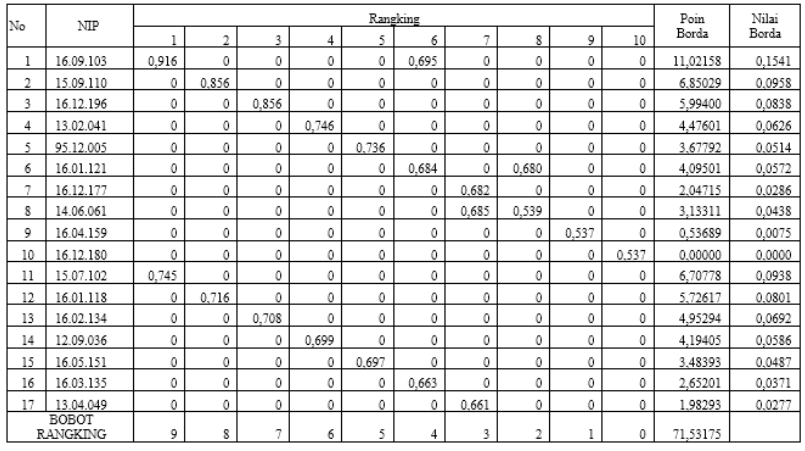

Tabel 6. Perhitungan Menggunakan Metode Borda Bagian Medis

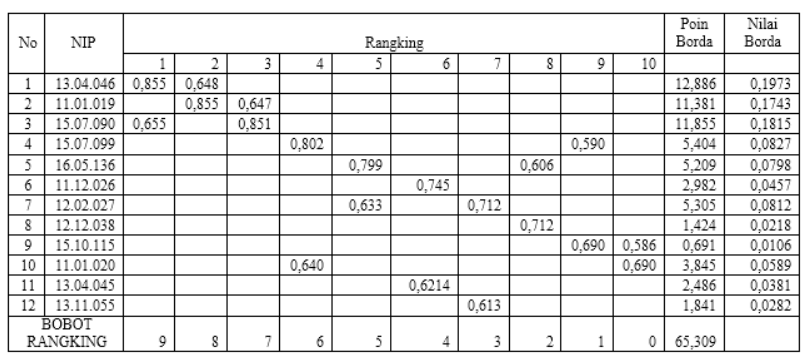

\section{Pengujian Akurasi}

Pengujian akurasi menggunakan confusion matriks. suatu metode yang biasanya digunakan untuk melakukan perhitungan akurasi pada konsep data mining. Rumus ini melakukan perhitungan dengan 4 keluaran, yaitu: recall, precision, acuraccy dan error rate. Berikut Skenario pengujian akurasi.

1. Data nilai convert ke skala karyawan pada kemuhammadiyahan dari ketentuan perusahaan (Non Medis dan medis). Skala penilaian yang digunakan antara $1-4$.

2. Setelah nilai didapatkan dilakukan perhitungan dengan menjumlahkan nilai keseluruhan dengan masing-masing kelompok penilai. Kemudian untuk penilai 1 dikali 0,4 sedangkan untuk penilai 2 dikali 0,6. Penggabungan nilai dari penilai 1 dan 2 kemudian nilai tersebut diambil 15 tertinggi untuk dibandingkan.

3. Hasil perhitungan metode sistem lama akan dibandingan menggunakan SPK dengan Smarter, Tanpa Smarter, Tanpa Borda dan Tanpa

\section{E. Confusion Matriks}

Pada penelitian ini menggunakan confusion matriks untuk mengetahui seberapa tigkat akurasi sistem yang telah dibuat.Rumus ini melakukan perhitungan dengan 4 keluaran, yaitu: recall, precision, acuraccy dan error rate. Rumus untuk menghitung akurasi seperti persamaan berikut ini.

$$
\begin{aligned}
& \text { Recall }=\mathrm{d} /(\mathrm{c}+\mathrm{d}) \\
& \text { Akurasi }=(\mathrm{a}+\mathrm{c}) /(\mathrm{a}+\mathrm{b}+\mathrm{c}+\mathrm{d}) \\
& \text { Precision }=d /(b+d) \\
& \text { Error Rate }=(b+c) /(a+b+c+d)
\end{aligned}
$$

Keterangan :

a: Jika hasil prediksi negatif dan data sebenarnya negatif 
b: Jika hasil prediksi positif dan data sebenarnya negatif

c: Jika hasil prediksi negatif dan data sebenarnya positif

b: Jika hasil prediksi positif dan data sebenarnya positif

Berdasarkan hasil uji akurasi menggunakan matriks confusion menghasilkan nilai akurasi sebagai berikut.

Tabel 11. Matriks Confusion Menggunakan Metode Smarter, TOPSIS \& Borda

\begin{tabular}{|c|c|c|}
\hline $\mathrm{a}$ & $:$ & 0 \\
\hline $\mathrm{b}$ & $:$ & 0 \\
\hline $\mathrm{c}$ & $:$ & 4 \\
\hline $\mathrm{d}$ & $:$ & 16 \\
\hline
\end{tabular}

\begin{tabular}{|c|c|c|}
\hline recall & $:$ & 0.8 \\
\hline precision & $:$ & 1 \\
\hline accuracy & $:$ & 0.8 \\
\hline error rate & $:$ & 0.2 \\
\hline
\end{tabular}

Tabel 12. Matriks Confusion Metode TOPSIS dan BORDA

\begin{tabular}{|c|c|c|}
\hline $\mathbf{a}$ & $:$ & 0 \\
\hline $\mathrm{b}$ & $:$ & 0 \\
\hline $\mathrm{c}$ & $:$ & 8 \\
\hline $\mathrm{d}$ & $:$ & 12 \\
\hline
\end{tabular}

\begin{tabular}{|c|c|c|}
\hline recall & $:$ & 0.6 \\
\hline precision & $:$ & 1 \\
\hline accuracy & $:$ & 0.6 \\
\hline error rate & $:$ & 0.4 \\
\hline
\end{tabular}

Tabel 13. Matriks Confusion Metode Smarter dan TOPSIS

\begin{tabular}{|c|c|c|}
\hline $\mathbf{a}$ & $:$ & 0 \\
\hline $\mathrm{b}$ & $:$ & 0 \\
\hline $\mathrm{c}$ & $:$ & 5 \\
\hline $\mathrm{d}$ & $:$ & 15 \\
\hline
\end{tabular}

\begin{tabular}{|c|c|c|}
\hline recall & $:$ & 0,7 \\
\hline precision & $:$ & 1 \\
\hline accuracy & $:$ & 0,7 \\
\hline error rate & $:$ & 0,25 \\
\hline
\end{tabular}

Tabel 14. Matriks Confusion Metode Smarter dan Borda

\begin{tabular}{|c|c|c|}
\hline $\mathbf{a}$ & $:$ & 0 \\
\hline $\mathrm{b}$ & $:$ & 0 \\
\hline $\mathrm{c}$ & $:$ & 6 \\
\hline $\mathrm{d}$ & $:$ & 14 \\
\hline
\end{tabular}

\begin{tabular}{|c|c|c|}
\hline recall & $:$ & 0.7 \\
\hline precision & $:$ & 1 \\
\hline accuracy & $:$ & 0,7 \\
\hline error rate & $:$ & 0,3 \\
\hline
\end{tabular}

Dari hasil pengujian menggunakan metode matriks confusion didapatkan hasil bahwa menggunakan metode smarter menghasilkan nilai akurasi sebesar 0.8 sedangkan tanpa metode smarter sebesar 0.6. Error rate untuk penggunaan smarter sebesar 0.2 sedangkan error rate tanpa menggunakan smarter 0.4. Kemudian hasil pengujian tanpa menggunakan borda dengan hasil akurasi sebesar 0.7 dan error rate sebesar 0.25 . Sedangkan pengujian menggunakan netode smarter dan borda akurasi sebesar 0,7 dan error rate 0,3 .

\section{KESIMPULAN}

Berdasarkan analisis, hasil penelitian dan pembahasan yang telah diutarakan sebelumnya maka dapat disimpulkan sebagai berikut:

1. Kombinasi model SMARTER, TOPSIS dan Borda dapat diimplementasikan kedalam aplikasi SPK berbasis webbase. Implementasi model ini telah dilakukan dengan sebuah prototipe dan dapat memberikan keputusan penetapan kenaikan golongan karyawan, namun masih secara general berdasarkan tingkat medis dan non medis.

2. Dalam uji akurasi menggunakan metode matriks confusion didapatkan hasil bahwa menggunakan metode smarter menghasilkan nilai akurasi sebesar 0.8 sedangkan tanpa metode smarter sebesar 0.6. Error rate untuk penggunaan smarter sebesar 0.2 sedangkan error rate tanpa menggunakan smarter 0.4. Kemudian hasil pengujian tanpa menggunakan borda dengan hasil akurasi sebesar 0.7 dan error rate sebesar 0.55. Sedangkan pengujian menggunakan netode smarter dan borda akurasi sebesar 0,7 dan error rate 0,3 .

3. Dalam penggunakan metode smarter membantu dalam menstabilkan kriteria. Semakin banyak kriteria maka semakin stabil nilai jarak antara bobot satu dengan yang lainnya. Dengan hasil $88.46 \%$ dengan jumlah kriteria sebanyak 26, sedangkan 16 kriteria sebesar $56.25 \%$,

4. Dalam uji korelasi sistem didapatkan nilai koefesien korelasi sebesar 0,479. Dengan begitu disimpulkan memiliki koefesien korrelasi sedang. Sedangkan dalam uji reabilitas r-hitung sebesar 0.478 sedangkan r-tabel 0.361, sehingga Apabila r-hitung > r-tabel maka instrumen untuk variabel bersangkutan dinyatakan realibel.

\section{REFERENSI}

kusrini, Konsep dan Aplikasi Sistem Pendukung Keputusan. Yogyakarta: Andi, 2007.

[2] M. Hamka, E. Utami, and A. Amborowati, "Sistem Pendukung Keputusan Kelompok Metode Topsis Dan Borda Untuk Penentuan Bakal Calon Haji,” pp. 109-114, 2014.

[3] D. Nofriansyah, Konsep Data Mining Sistem Pendukung Keputusan. Yogyakarta: Deepublish, 2014.

[4] A. A. Larasati, A. H. Setianingrum, and L. K. Wardhani, "Development decision support system of choosing medicine using TOPSIS method (Case study: RSIA Tiara)," Proc. - 6th Int. Conf. Inf. Commun. Technol. Muslim World, ICT4M 2016, pp. 160-165, 2017, doi: 10.1109/ICT4M.2016.37.

[5] M. Husein and A. Amborowati, "Sistem Pendukung Keputusan Kelompok Penilaian Kinerja Kepala Sekolah SMP Berprestasi,” Konf. Nas. Sist. Inform. 2017, pp. 125130, 2017.

[6] A. Sunyoto, P. Studi, T. Informatika, and S. C. Dosen, "Sistem pendukung keputusan seleksi penerimaan dosen di stmik amikom yogyakarta menggunakan metode topsis dan borda," vol. 10, no. 2, pp. 44-61, 2017.

[7] S. Mallu, "Sistem pendukung keputusan penentuan karyawan kontrak menjadi karyawan tetap menggunakan metode topsis," J. Ilm. Teknol. dan Inf. Terap., vol. 1, no. 2, pp. 36-42, 2015.

[8] H. Eko Sudrajat, Kusrini, "Sistem Pendukung Keputusan Penentuan Dosen Dengan Kinerja Terbaik," Knsi 2018, no. May, pp. 392-398, 2018.

[9] M. Aan, R. Rahim, S. Tinggi, and I. Manajemen, "Technical Approach of TOPSIS in Decision Making," Int. J. Recent Trends Eng. Res., vol. 3, no. 8, pp. 58-64, 2017, doi: 10.23883/ijrter.2017.3388.wpyuj.

[10] D. Haryanti, H. Nasution, and A. S. Sukamto, "Sistem Pendukung Keputusan Seleksi Penerimaan Mahasiswa Pengganti Beasiswa Penuh Bidikmisi Universitas Tanjungpura Dengan Menerapkan Metode SMARTER," $J$. Sist. dan Teknol. Inf., vol. 1, no. 1, pp. 1-7, 2016, [Online]. Available:

https://jurnal.untan.ac.id/index.php/justin/article/view/128 
$76 / 0$.

[11] S. M. Chen, S. H. Cheng, and T. C. Lan, "Multicriteria decision making based on the TOPSIS method and similarity measures between intuitionistic fuzzy values," Inf. Sci. (Ny)., vol. 367-368, pp. 279-295, 2016, doi: 10.1016/j.ins.2016.05.044. 